\title{
ひずみエネルギー密度関数を用いた 遮水シートの二軸引張変形挙動評価
}

\author{
狩野真吾 1 ・ 小田勝也 $2 \cdot$ 近藤三樹郎3
}

\begin{abstract}
本研究では廃棄物最終処分場に敷設される軟質PVC, HDPE，SMePEの各遮水シートを対象に，ひずみエネルギ 一密度関数（W関数）を用いた遮水シートの二軸引張変形時の応カーひずみ曲線の推定精度を検討した。軟質 PVC，HDPE，SMePEの各遮水シートについて，一軸拘束二軸引張試駼結果からそれぞれの関数を求め, 均等二軸 引張変形時の応力ーひずみ曲線を計算した。 この計算値と二軸引張試験における実測値とを比較した結果, 軟

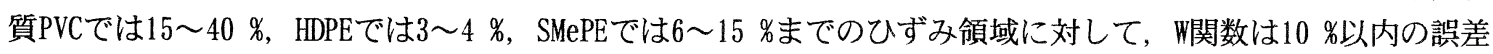
で実験值の応力を推定可能であることがわかった．ここで, 敷設面不陸に追従した際の軟質PVCに発生するひ ずみは最大でも 15 名程度であるという既往の研究結果を考慮すると, たとえば軟質PVCの裏込不陸への追従性 を検討する場合，関数による推定手法は十分に適用可能であると考えられる.
\end{abstract}

キーワード : 遮水シート, 二軸引張試験, ひずみエネルギー密度関数, 応力ーひずみ曲線

\section{1.はじめに}

廃棄物最終処分場に敷設される遮水シートの性能值 を規定する場合, 遮水シートに発生する応力状態を考慮 し，それを再現できるような試験方法および解析手法に よって検討がなされるべきである. これに対し, 設計に 用いられる遮水シ一トの性能値は一軸引張試験による結 果が主となっている. 海面処分場の場合, 遮水シートは 地盤の不等沈下，自重や上載荷重等の引き込み力による 引張変形, 敷設面不陸への追随, 突起物の貫入等, 二次 元的な変形挙動を示す場合が少なくない. 陸上処分場お よび海面処分場に敷設される遮水シートの力学的性質に 関して，これまでさまざまな検討が行われてきた．その 結果, 突起物の貫入による遮水シートの変形破断挙動 3), 海面処分場に敷設された遮水シ一トの変形状態", 地 盤の不等沈下への変形追随性の評価手法, 6) 等が明らか にされた. しかし, 二軸応力下での遮水シートの性能值 は設計に反映されていないのが現状である，その理由と しては, 二軸応力下での遮水シートの挙動を検証するた めの二軸引張試験が一軸引張試験に比べて手間がかかり, 工学的には一軸引張試験がより汎用性の高い試験方法で あること等が挙げられる。

一方, ゴム材料の力学を対象とした研究分野では, ゴム材料のひずみエネルギ一密度関数（以下，䀶数之 記す）の関数形が明らかにされ，ゴム材料の二軸引張 変形時における応力ひずみ挙動の憫数による検討がな されている゙.これに対し，関数による評価手法が遮水
シートの設計に用いられた例はない。 遮水シートの力学 的性質を正しく把握し，その結果が遮水シートの設計に 反映されることは，管理型廃棄物最終処分場の信頼性設 計法の構築に必要不可欠な検討事項である.

そこで, 本研究では, 遮水シートの二軸引張変形時 の挙動を明らかにするため, シート供試体を用いた二軸 引張試験を実施した．その際，供試体の厚さの変化，お よび引張速度が変形挙動に及ぼす影響について考虑した。 また, ゴム材料の関数に関する上述の検討例を基礎に して, 一軸拘束二軸引張試験結果を用いて遮水シートの W関数を求めた. さらに, 二軸引張変形時の応力ーひず み曲線について実験值と関数を用いた計算值とを比較 することにより, 関数による遮水シートの応力ーひず み曲線の推定精度を検討した.

\section{2. 二軸引張試験}

\section{（1）二軸引張試験機}

二軸引張試験は大阪府立産業技術総合研究所所有の二 軸引張試験機を使用して行った. 試験機の概略図を図一 1 に, 装置の写真を写真一 1 に, 主な仕様を表一 1 にそ れぞれ示す。この試験機は水平軸，鉛直軸が個別にコン ピュータ制御されており，鉛直軸を自動荷重一ひずみ制 御で荷重拘束し, 水平軸に荷重をかけて引張る一軸拘束 二軸引張試験，および鉛直軸，水平軸に均等に同時に荷 重を負荷する均等二軸引張試験を行うことが可能である. 試料のつかみ部は試料の1辺あたり各4個のチャックで均

1正会員, 東北大学大学院環境科学研究科, 研究員（广980-8579宮城県仙台市青葉区荒巻字青葉6-6-20)

2正会員, 国土技術政策総合研究所 沿岸防災研究室, 室長 (T239-0826 神奈川県横須賀市長瀬3-1-1)

3正会員, 土木シート技術協会, 理事（東ソー・ニッケミ株式会社（テ105-0014 東京都港区芝2-5-10）） 
表一 1 二軸引張試験機の主な仕様

\begin{tabular}{|l|l|}
\hline 有効試験片寸法 & 最大 $200 \mathrm{~mm} \times 200 \mathrm{~mm}$ \\
\hline 最大荷重容量 & X軸, Y軸ともに $49 \mathrm{kN}$ \\
\hline 最大測定変位 & X軸, Y軸ともに $400 \mathrm{~mm}$ \\
\hline 引張速度範囲 & $0.1 \sim 500 \mathrm{~mm} / \mathrm{min}$ \\
\hline 試験温度範囲 & $-20 \sim 200^{\circ} \mathrm{C}$ \\
\hline
\end{tabular}

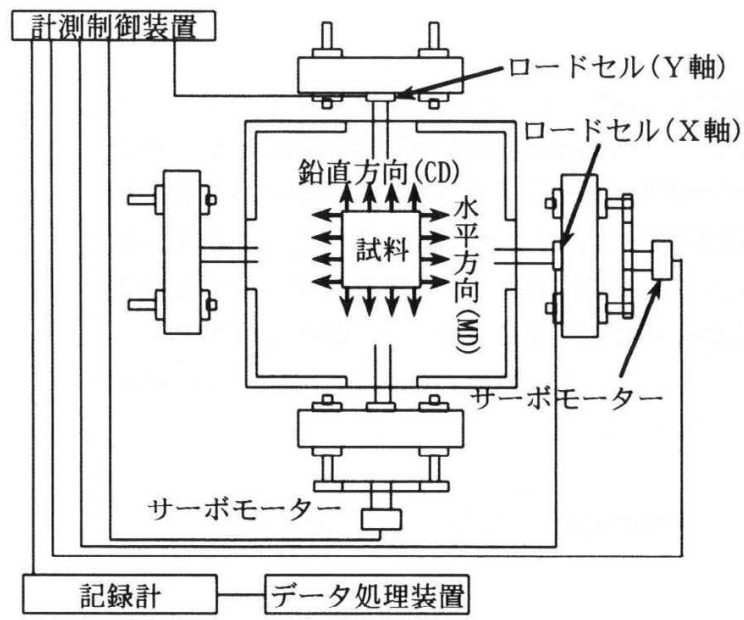

図-1 二軸引張試験機の概念図

等に把持し, 試験時に各チャックが試験片の自由変形に 応じて連動し移動することが可能である.

一軸拘束二軸引張試験および均等二軸引張試験の各試 験方法と現実の遮水シートの変形挙動の対応については, 以下のように考えられる. すなわち, 法面平行方向はシ 一ト相互が溶着され変形が拘束されているのに対し, 法 面垂直方向はシートの自重や上載荷重による引き込み力 によって引張変形が生じやすい，一軸拘束二軸引張試験 はこのような片側を拘束された状態でのシートの変形挙 動に対応する. また, 突起物が貫入した場合, あるいは 遮水シート敷設面に陥没等があり上載圧等の影響でシー トが陥没内に向かって変形する場合等においては, 遮水 シートには局所的に等方的な引張応力, すなわち均等二 軸応力が発生すると考えられる.

\section{（2）試験に使用した材料}

二軸引張試験の供試体には, 海面処分場への施工実績 が多いポリ塩化ビニル系シート（軟質PVC : 厚さ 3.0 mim），およひ陸上処分場で施工実績のあるポリエチレン 系シート (HDPE : 厚さ $1.5 \mathrm{~mm}, \mathrm{SMePE}:$ 厚さ $3.0 \mathrm{~mm}$ ) の計 3種類の材料を使用した. 供試体の寸法と形状は一辺が $15 \mathrm{~cm}$ 正方形とした.

\section{（3）試験方法}

試験の手順はまず， $15 \mathrm{~cm} \times 15 \mathrm{~cm}$ の大きさに成形した 供試体を二軸引張試験機の試料つか夕部に設置し, チャ ックで均等に把持した. その後, 一軸拘束二軸引張試験 を50 mm/minの一定速度で, また, 均等二軸引張試験を

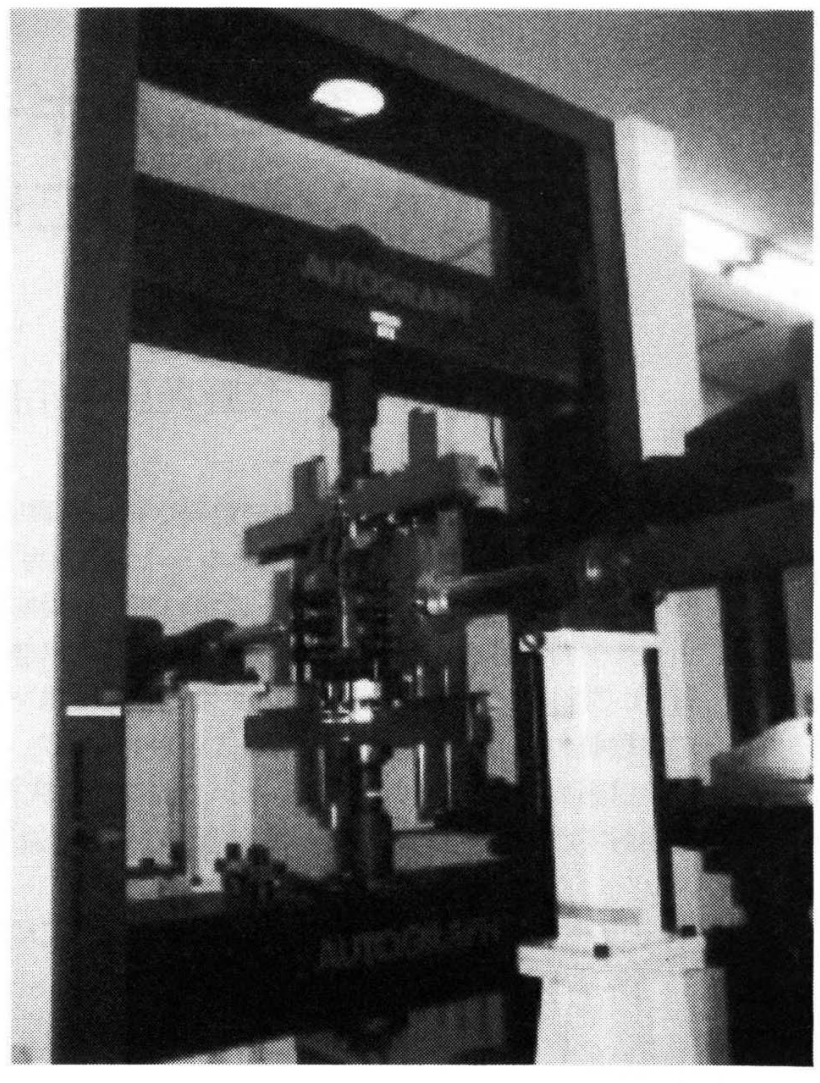

写真－1 二軸引張試験機（大阪府立産業技術総合研究所所有）

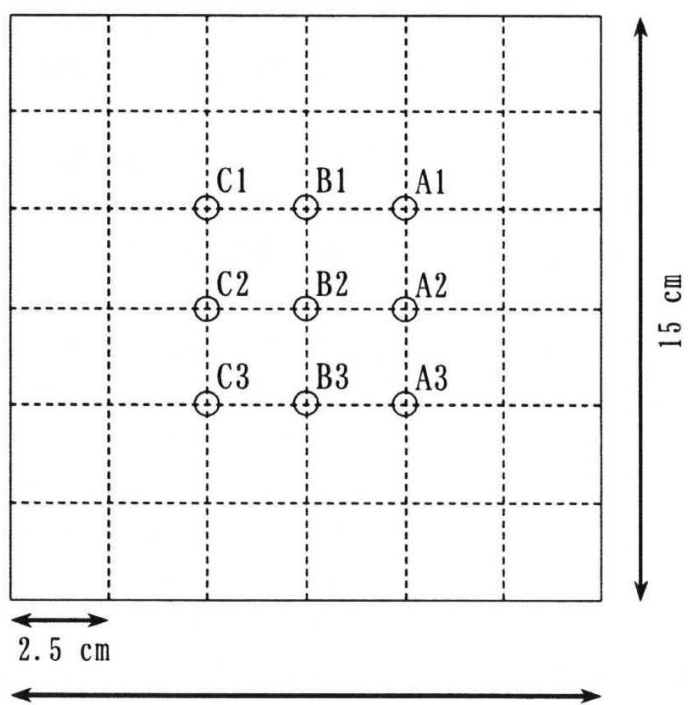

$15 \mathrm{~cm}$

図ー2 供試体の寸法および厚さの測定箇所

表 -2 試験ケース

\begin{tabular}{|c|c|c|c|c|c|}
\hline & 軟質PVC & HDPE & SMePE \\
\hline \multicolumn{3}{|c|}{ 一軸拘束二軸引張試験 } & 0 & $\mathrm{O}$ & 0 \\
\hline \multirow{3}{*}{$\begin{array}{l}\text { 均等二軸 } \\
\text { 引張試験 }\end{array}$} & \multirow{2}{*}{$\begin{array}{c}\text { 引張速度 } \\
(\mathrm{mm} / \mathrm{min})\end{array}$} & 5 & & 0 & 0 \\
\hline & & 50 & O & 0 & O \\
\hline & \multicolumn{2}{|l|}{ 厚さ測定 } & 0 & & \\
\hline
\end{tabular}




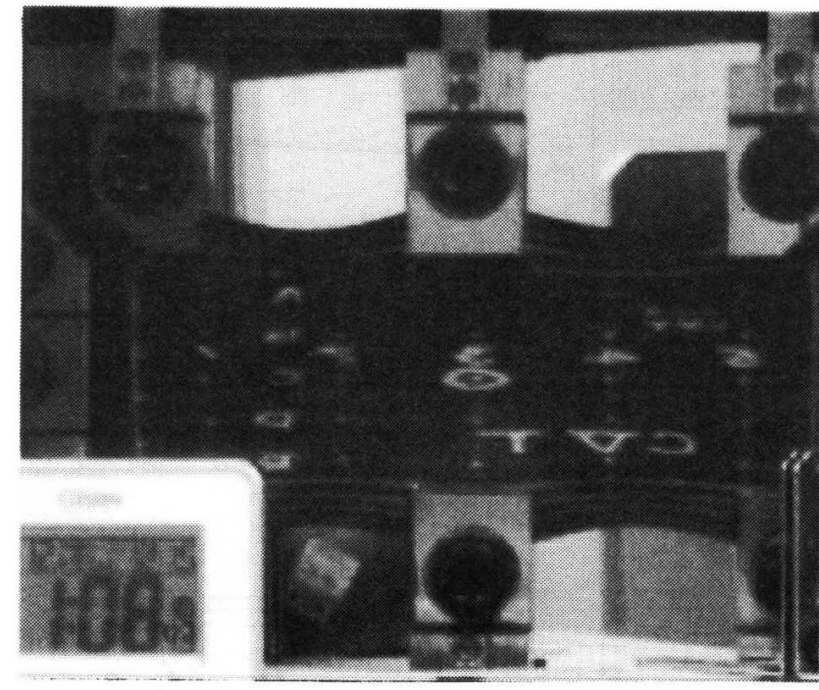

写真－2 一軸拘束二軸引張試験で変形する軟質 PVC

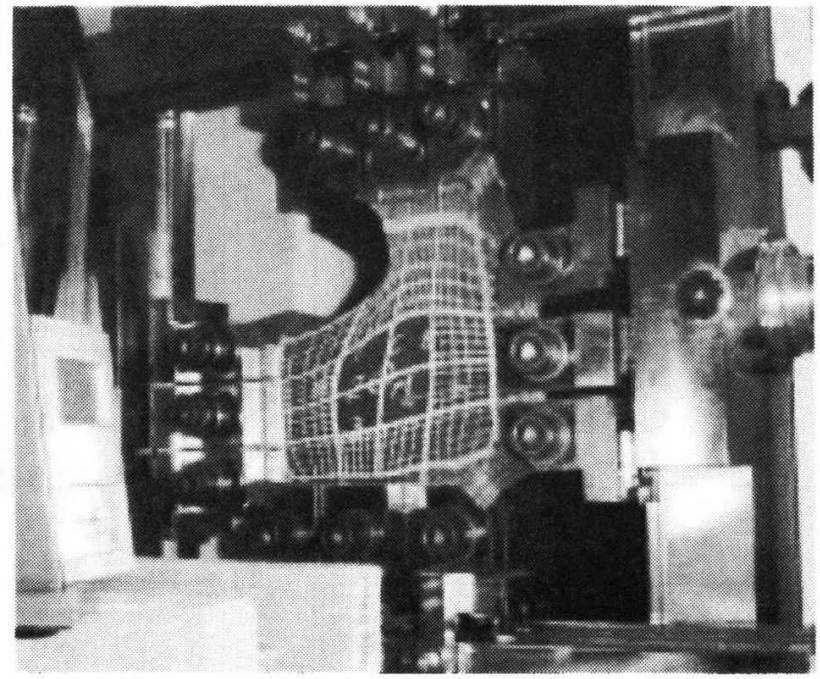

写真－３－軸拘束二軸引張試験で破断する軟質 PVC
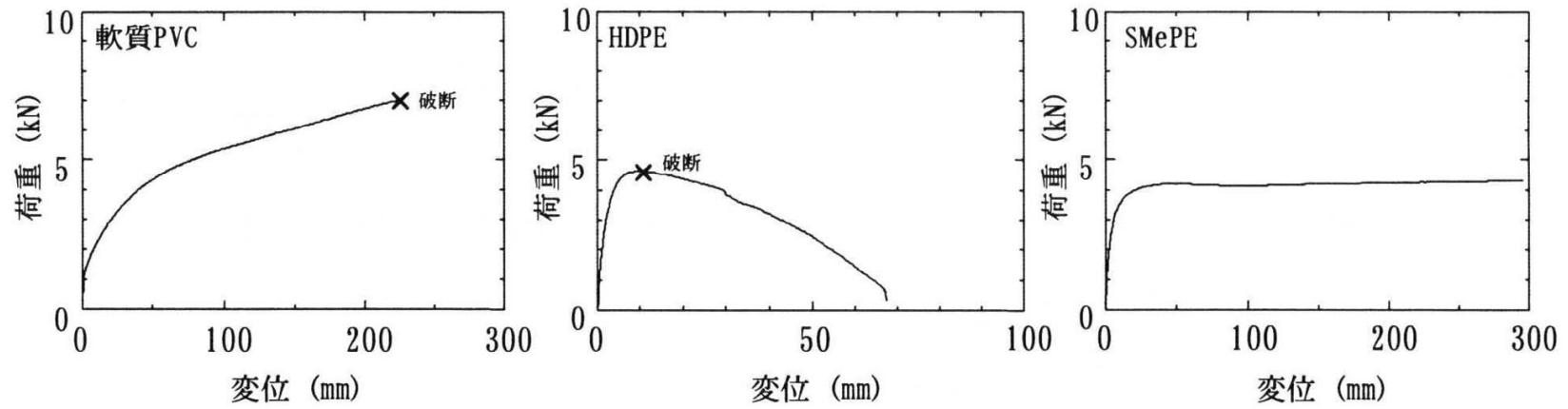

図-3 一軸拘束二軸引張変形時の荷重一変位曲線
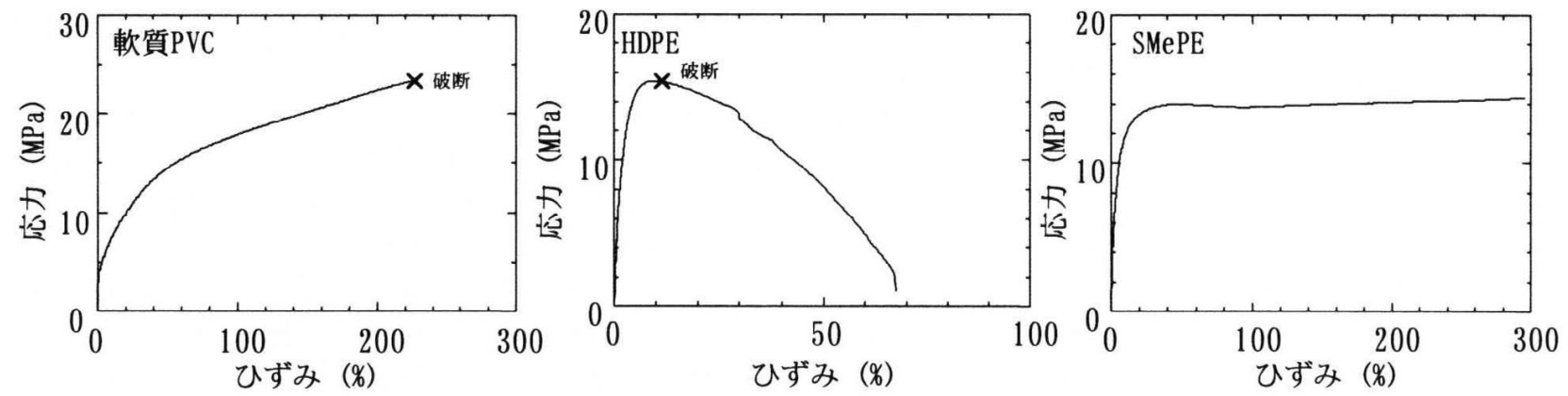

図-4 一軸拘束二軸引張変形時の応力ーひずみ曲線

$50 \mathrm{~mm} / \mathrm{min}$ あるいは $5 \mathrm{~mm} / \mathrm{min}$ の定速度で実施し, 供試体 が破断するまでの荷重と変位を計測した. その際, 荷重 はロードセルで測定し, 変位はクロスヘッドの移動量 (チャック間距離) を測定した. なお, 試験室の温度は $23^{\circ} \mathrm{C}$ 保ち, また, 試験回数は1回とした.

\section{（4）厚さの測定方法}

均等二軸引張変形中の供試体の厚さの変化を把握する ため, 試験中に数回, 載荷を数分程度一時的に停止し, 供試体の厚さを外側キャリパーゲージで測定した。供試 体にはあらかじめ格子線を引いておき（図一2），厚さ の測定は中心部の9点（A1〜 $33, \mathrm{~B} 1 \sim \mathrm{B} 3, \mathrm{Cl} \sim \mathrm{C} 3)$ を対象
に行った. なお，あらかじめ別途の試験で供試体の破断 伸びを測定しておき，その破断伸びを 5 等分した各段階 で初期状態も含めて5回測定した.

（5）試験ケース

試験ケースを表ー 2 に示す。

\section{3. 試験結果}

（1）一軸拘束二軸引張時の変形およひ破断挙動

供試体の変形の様子を写真 -2 に, 破断の様子を写真 

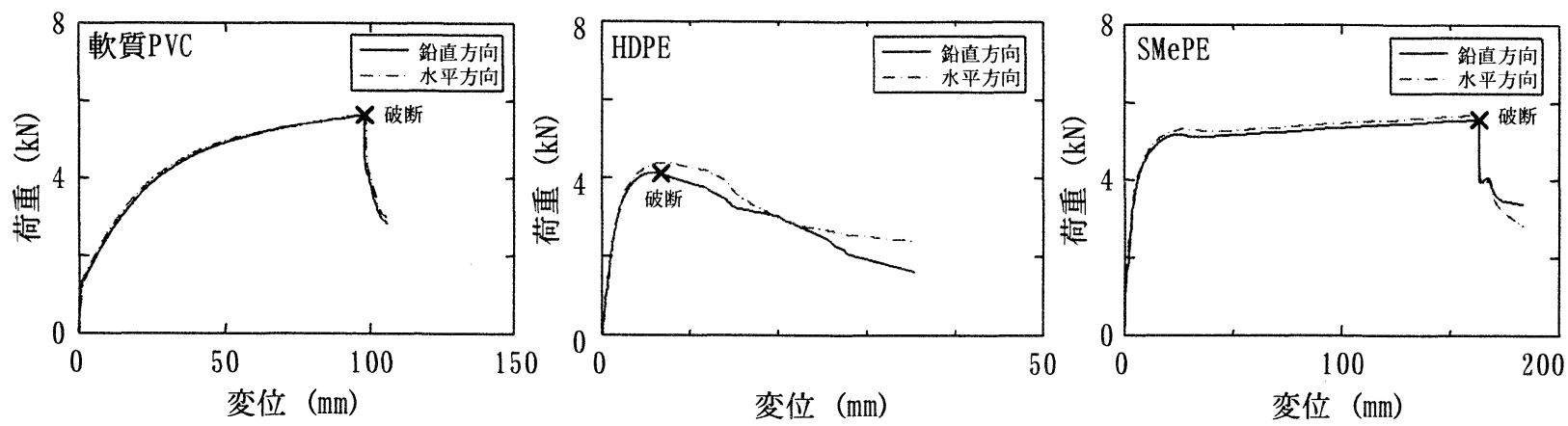

図-5 二軸引張変形時の荷重一変位曲線
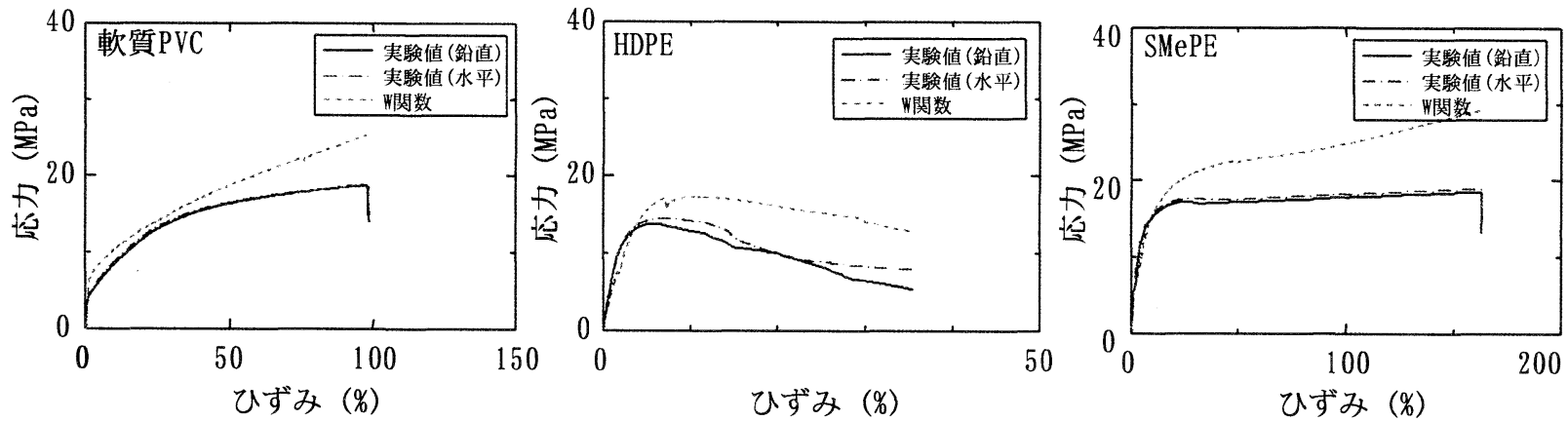

図一6 二軸引張変形時の応力ーひずみ曲線に関する試験值とW 関数による計算值との比較

ー3にそれぞれ示す．破断は，いずれの供試体のケース も供試体のつかみ部分（角部）が引き裂かれることによ り発生した.これは, 隣り合うチャック間において局所 変形による応力集中が発生したためと考えられる. とく に角部は供試体が縦, 横方向に引つ張られるため, 他の 部分より大きな応力集中が作用したと考えられる．この ような破断は引張変形時の二軸応力が原因で発生したも のではないため, 材料の二軸応力下における破断時性能 を評価することはできなかった。

軟質PVC, HDPE，SMePE各供試体の荷重と変位の関係を 図ー3に，測定した荷重を断面積で除して得られた応力 (MPa) と初期の試料幅に対するひずみとの関係を図一 4 にそれぞれ示す. 図中の×印は破断点を示している. 荷重一変位曲線および応力ーひずみ曲線ともに, 軟質 PVCは変位（ひずみ）の増加とともに連続的に荷重（応 力）が増加し, 明確な降伏点は存在しなかった. 一方, ポリエチレン系供試体であるHDPEとSMePEは変形初期に 急激に荷重（応力）が増加した. HDPEは荷重（応力）の 最大点で破断が発生した。一方，SMePEは変位が300 m を越えた時点で試験を終了した。これら3種類の供試体 の荷重（応力）増加傾向は一軸引張変形時に一般的に見 られる挙動と類似するものである. なお，図中における 最大点は供試体のつかみ部分における破断を示し，これ は前述のように供試体の真の破断点とは異なる. なお, 変形のごく初期に見られる曲線の急激な立ち上がり（た とえば軟質PVCにおいて約1 kNの荷重まで，もしくは約5 $\mathrm{MPa}$ の応力までを指す））は試験機の測定上の誤差の影 響を受けた結果であり，供試体の本来の変形挙動ではな
い.

\section{（2）均等二軸引張時の変形および破断挙動}

均等二軸引張試験における供試体の破断は, 一軸拘束 二軸引張試験の時と同様, 供試体の角部から発生した. これもやはり，つかみ部分で発生した応力集中が原因と 考えられる.

軟質PVC, HDPE，SMePE各供試体の荷重と変位の関係を 図ー 5 に, 荷重を断面積で除して得られた応力（MPa） 亡所期の試料幅に対するひずみとの関係を図ー6に示す. 図中の実線は鉛直方向の挙動を, 破線は水平方向の挙動 をそれぞれ示している. また，図中の×印は破断点を示 している. 鉛直方向と水平方向の曲線の傾向はどの供試 体も同じことから, 供試体は両軸方向に均等に変形した ことがわかる．軟質PVCは変位（ひずみ）に対して荷重 （応力）が徐々に増加したのに対し，ポリエレン系供 試体であるHDPEとSMePEは変形初期に急激に荷重（応 力）が増加した. この荷重増加傾向は, 一軸引張変形時 や一軸拘束二軸引張変形時の挙動と類似するものである. なお, 変形のごく初期に見られる曲線の急激な立ち上が りは一軸拘束二軸引張試験結果と同様, 試験機の測定上 の誤差の影響を受けた結果である.

\section{（3）引張速度の違いが二軸変形挙動に及ぼす影響}

2種類のポリエチレン系シートについて, 引張速度を $50 \mathrm{~mm} / \mathrm{min} お よ ひ ゙ 5 \mathrm{~mm} / \mathrm{min} ゙$ それぞれ一定とした時の試験 結果を図ー 7 に示す。ただし，図中の曲線はどちらの引 張速度についても鉛直, 水平両軸の算術平均值を示して 


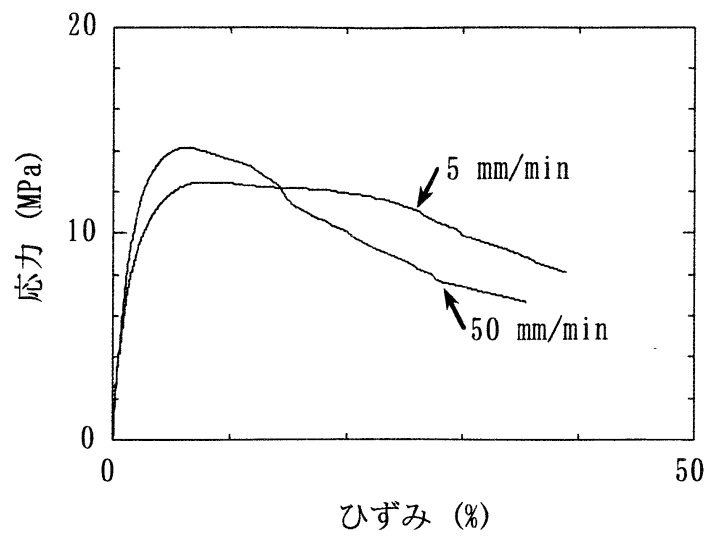

(a) $\mathrm{HDPE}$

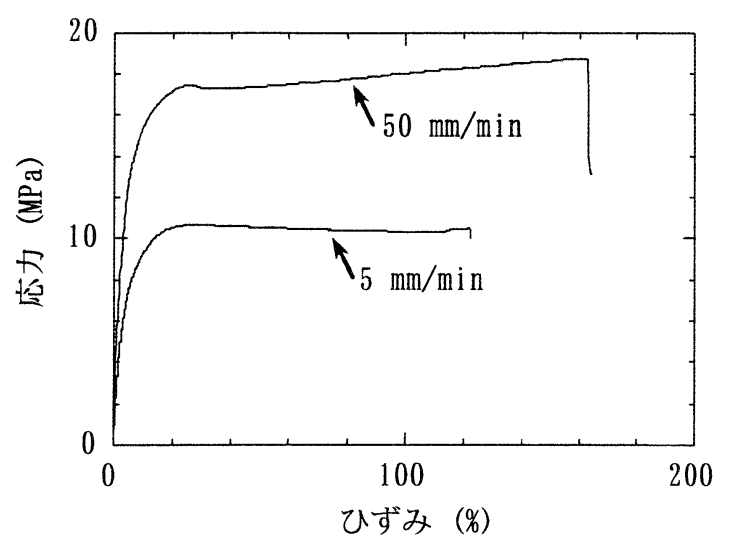

(b) SMePE

図－７異なる引張速度における二軸引張試験結果

いる. 原点と 5 \%ひずみ時のプロットを直線で結んだ $5 \%$ 割線弾性係数は, HDPEの $50 \mathrm{~mm} / \mathrm{min}$ では $14.0 \mathrm{MPa}, 5$ mm/minでは11.9 MPaだった.一方SMePEの50 mm/minでは $12.8 \mathrm{MPa}, 5 \mathrm{~mm} / \mathrm{min}$ では7.5 MPaだった. また, 最大応力 は, HDPEの50 mm/minでは $14.2 \mathrm{MPa}, 5 \mathrm{~mm} / \operatorname{minでは12.4~MPa~}$ だった. 一方SMePEの50 mm/minでは $18.8 \mathrm{MPa}, 5 \mathrm{~mm} / \mathrm{min}$ は10.6 MPaだった. 以上の結果から, 一軸引張変形時に おいて一般的に見られるように, 二軸引張変形時もまた, 引張速度が大きい方が遮水シートは高弾性, 高強度であ ると言うことができる.

\section{(4) 二軸引張変形時の厚さの変化について}

軟質PVCについて，図ー8に厚さを測定したケースの 応力ーひずみ曲線を示す．厚さの測定は図中の矢印の点 で行った. 載荷を一時的に停止した影響による応力緩和 が見られる.

厚さの測定結果を図ー9に示す．測定箇所ごとの厚 さのばらつきは最大でも $0.1 \mathrm{~mm}$ 程度であり, 供試体全体 が均一に変形したことがわかる. 9箇所の厚さの算術平 均值は, 変形が進行するにつれて, $3.0 \mathrm{~mm}, 2.2 \mathrm{~mm}, 1.7$ $\mathrm{mm}, 1.3 \mathrm{~mm}, 1.1 \mathrm{~mm}$ 之減少した.

次に, 鉛直, 水平方向への伸び量と厚さから計算し た供試体の体積を変形前の体積で規格化した結果を図一

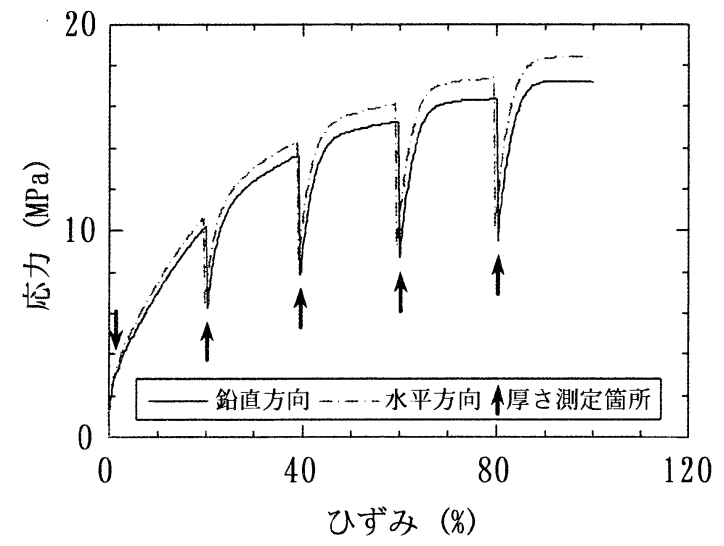

図一8 厚さ測定時の軟質 PVCの応力ーひずみ曲線

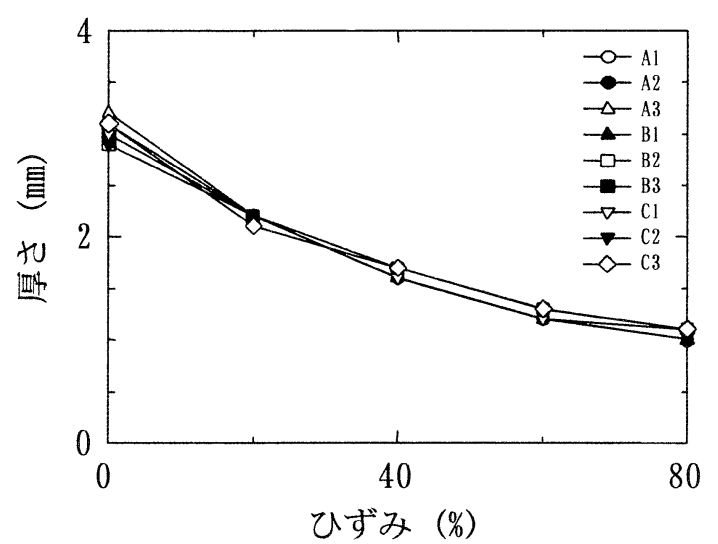

図-9 二軸引張時における軟質 PVC の厚さ変化

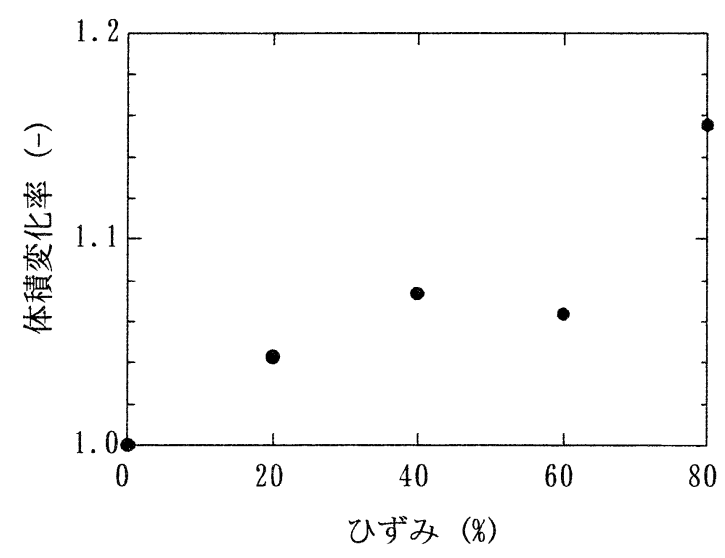

図一 10 二軸引張時における軟質 PVC の体積変化率

10 に示す．その結果，供試体の体積は変形とともに 徐々に増加し， 80 \%ひずみでは変形前の約1.15倍になつ た. 体積が増加した理由として, 高分子鎖の切断に伴う ミクロボイドの発生, 拡大の可能性が考えられるが, 詳 細については不明である。

\section{W関数を用いた二軸引張変形時の応カーひずみ}

\section{曲線の推定}




\section{(1) W 関数の求め方}

W 関数は数学的大変形理論として扱われ, 主に弾性体 を対象にして研究が進められてきた。一軸伸張を例にと ると, 試験片を伸張させるのに外力がなした単位体積当 りの仕事は変形前の体積を基準にすると,

$$
W(\lambda)=\int_{1}^{\lambda_{1}} \sigma d \lambda
$$

で与えられる，入は伸張比，W は弾性体をひずませる仕 事であるが，W は同時に弾性体内にひずみエネルギーと して貯えられるエネルギ一でもある.ここで, 厳密には 高分子化合物は非弾性の性質も持つため, 変形時に外部 からなした仕事はそのまま内部の弾性エネルギーの増加 と等しくならない．ここでは仮に物体を弾性体とみなし て外力と変形の関係からWを決定すると, 応力とひずみ の関係はこのWにより求まる. また，W は物体が非弾性 の性質を帯びる場合も外力ーひずみの関係を推定するの に唯一の手がかりとなる関数である ${ }^{8}$.

変形時に非圧縮性を仮定すると, 二次元応力状態での 応力, 伸張比とひずみエネルギ一密度関数の偏微分值と の関係は以下のように表される ${ }^{8}$.

$$
\begin{aligned}
& \frac{\partial W}{\partial I_{1}}=\frac{1}{2\left(\lambda_{1}^{2}-\lambda_{2}^{2}\right)}\left[\frac{\lambda_{1}^{3} \sigma_{1}}{\lambda_{1}^{2}-\left(\lambda_{1} \lambda_{2}\right)^{-2}}-\frac{\lambda_{2}^{3} \sigma_{2}}{\lambda_{2}^{2}-\left(\lambda_{1} \lambda_{2}\right)^{-2}}\right] \\
& \frac{\partial W}{\partial I_{2}}=\frac{1}{2\left(\lambda_{2}^{2}-\lambda_{1}^{2}\right)}\left[\frac{\lambda_{1} \sigma_{1}}{\lambda_{1}^{2}-\left(\lambda_{1} \lambda_{2}\right)^{-2}}-\frac{\lambda_{2} \sigma_{2}}{\lambda_{2}^{2}-\left(\lambda_{1} \lambda_{2}\right)^{-2}}\right] \\
& \text { ここに,}
\end{aligned}
$$

$$
\begin{aligned}
& I_{1}=\lambda_{1}^{2}+\lambda_{2}^{2}+\lambda_{1}^{-2} \lambda_{2}^{-2} \\
& I_{2}=\lambda_{1}^{-2}+\lambda_{2}^{-2}+\lambda_{1}^{2} \lambda_{2}^{2}
\end{aligned}
$$

均等二軸変形時は $\lambda_{1}=\lambda_{2}=\lambda$ なので, 応力は次式のよ うに表される.

$$
\sigma=2\left(\lambda-\frac{1}{\lambda^{5}}\right)\left(\frac{\partial W}{\partial I_{1}}+\lambda^{2} \frac{\partial W}{\partial I_{2}}\right)
$$

ここに

$$
\begin{aligned}
& I_{1}=2 \lambda^{2}+\lambda^{-4} \\
& I_{2}=\lambda^{4}+2 \lambda^{-2}
\end{aligned}
$$

また, 一軸拘束二軸引張変形での応力は次のように表 される ${ }^{8)}$.

$$
\begin{aligned}
& \sigma_{1}=\frac{2}{\lambda_{1}}\left(\lambda_{1}^{2}-\frac{1}{\lambda_{1}^{2}}\right)\left(\frac{\partial W}{\partial I_{1}}+\frac{\partial W}{\partial I_{2}}\right) \\
& \sigma_{2}=2\left(1-\frac{1}{\lambda_{1}^{2}}\right)\left(\frac{\partial W}{\partial I_{1}}+\lambda_{1}^{2} \frac{\partial W}{\partial I_{2}}\right)
\end{aligned}
$$

ここに,

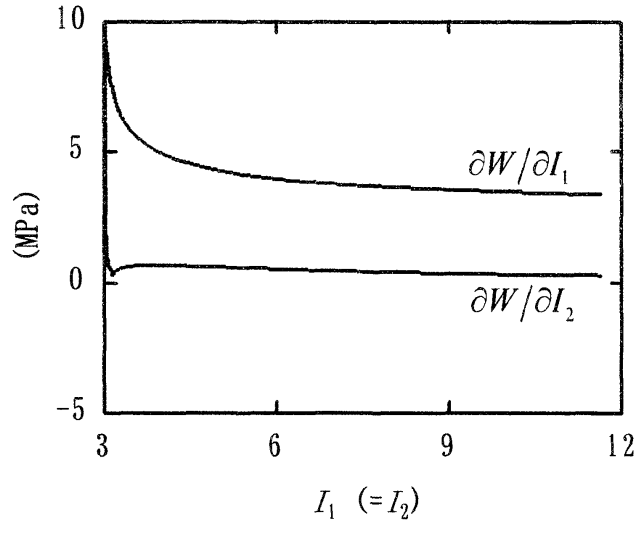

図-11 Wの偏微分値の計算結果

$$
I_{1}=I_{2}=\lambda_{1}^{2}+\frac{1}{\lambda_{1}^{2}}+1
$$

一軸拘束二軸引張試験での実測值である $\sigma_{1}, \sigma_{2}, \lambda_{1}$ を式 (9)，式(10)に代入することにより， $I_{i}$ と $\partial W / \partial I_{i}$ の関係 が求まる.この関係を利用して, 均等二軸引張変形時の 供試体の応力ーひずみ曲線を推定することが可能となる.

\section{（2）一軸拘束二軸引張試験結果に基づく W関数の推定}

$W$ の偏微分值 $\partial W / \partial I_{1}, \partial W / \partial I_{2}$ を求めるため, 式(9), 式(10)を次式のように変形した.

$$
\begin{aligned}
& \frac{\partial W}{\partial I_{1}}=\frac{1}{2\left(\lambda_{1}^{2}-1\right)}\left[\frac{\lambda_{1}^{3} \sigma_{1}}{\lambda_{1}^{2}-\lambda_{1}^{-2}}-\frac{\sigma_{2}}{1-\lambda_{1}^{-2}}\right] \\
& \frac{\partial W}{\partial I_{2}}=\frac{1}{2\left(1-\lambda_{1}^{2}\right)}\left[\frac{\lambda_{1} \sigma_{1}}{\lambda_{1}^{2}-\lambda_{1}^{-2}}-\frac{\sigma_{2}}{1-\lambda_{1}^{-2}}\right]
\end{aligned}
$$

軟質 PVC について, 式(12), 式(13)の $\sigma_{1}, \sigma_{2}, \lambda_{1}$ に試験 値を代入することにより求められた $\partial W / \partial I_{1}, \partial W / \partial I_{2}$ を, $I_{1}$ に対してプロットしたものを図ー 11 に示す. $\partial W / \partial I_{1}, \quad \partial W / \partial I_{2}$ はいずれも $I_{1}$ の，したがって伸張比 $\lambda$ の複雑な関数であることがわかる. すなわち, $\partial W / \partial I_{1}$ は小変形領域では変形の増加に伴い最初は急激に低下す るが，極小值をとった後は約 $9 \mathrm{MPa}$ 付近で極大值を取り, その後は変形とともに徐々に減少した. 一方, $\partial \mathrm{W} / \partial \mathrm{I}_{2}$ は小変形領域において変形の増加に伴い最初急激に増加 し，極大值を取った後は $0.2 \sim 0.7 \mathrm{MPa}$ の間で変曲しな がら徐々に減少した。

（3）W関数を用いた応力ーひずみ曲線の推定精度 
上述の方法で求められた $\partial W / \partial I_{1}, \quad \partial W / \partial I_{2}$ をの試

験値とともに式(2)に代入し，均等二軸引張変形時の応 力を計算した結果を図一 6 に示す。図中の破線は計算值 を，実線および一点鎖線は試験值をそれぞれ示す．なお， 横軸は伸張比をひずみに変換して表示している。.また, 試験值の応力は測定值である荷重を断面積で除して計算 し，ひずみは初期の供試体幅に対する伸び率を計算した 結果である.

試験値と計算値とを比較した結果，どの供試体も低 ひずみ側では両者の傾向はよく一致したが，高ひずみ側 では大きなずれが生じた．その理由としては，二軸引張 変形では伸張比の 2 乗の項が $\partial W / \partial I_{2}$ にかかるため, 高 ひずみ側では小さな誤差が無視できなくなった，あるい は, W 関数は物質を弾性体と仮定しているが，高ひずみ 側では供試体の非弾性的性質が無視できなくなった，等 が考えられる. 軟質 PVCに比べ，ポリエチレン系シート の方がその傾向が顕著だった.

図ー 12 は, W 関数を用いて計算した応力值が試験值 とどの程度一致するかを示した図である．縦軸は次式に よる計算結果である.

$$
\sigma_{\text {ratio }}=1-\frac{\left|\sigma_{\mathrm{m}}-\sigma_{\mathrm{c}}\right|}{\sigma_{\mathrm{m}}}
$$

ここに， $\sigma_{\mathrm{m}}$ は試験値， $\sigma_{\mathrm{c}}$ は計算值である.

その結果, 応力の試験値と計算值が 80 \%以上一致す る, すなわち, 両者の差異が $20 \%$ 未満である変形領域 は, 軟質 PVC では約 $10 \%$ 60\%, HDPE では約 $2 \%$ 10\%, SMePE では約 4 \%〜30\%の各ひずみ範囲だった. さらに, 両者の差異が 10 \%未満である変形領域は, 軟質 PVC では 約 $15 \% \sim 40 \%$, HDPE では約 $3 \% \sim 4 \%$, SMePE では約 $6 \%$ 〜15 \%の各ひずみ範囲だった.

ここで, 実際の廃棄物海面処分場において, 遮水シ 一トに局所的な二軸応力が発生すると考えられる敷設面 不陸への追随時の挙動を土槽実験により検証した結果, 静的な環境下で不陸に追随する軟質 PVC 製遮水シートに 発生したひずみは最大でも 15 程度であった ${ }^{9}$. この結 果を考慮すると，たとえば軟質 PVC の裏込不陸への追随 性を検討する場合, W 関数を用いて計算した応力值は実 際の值に対して 90 \%以上の推定精度を有していること から，W 関数による推定手法は十分に適用可能であると 考えられる. ただし, 本推定手法では遮水シートの変形 の時間依存性や温度依存性は考慮されていないため, 実 際の推定においてはこれらの諸特性を十分に考慮するこ とが望ましい.

\section{5. まとめ}

本研究では, 管理型廃棄物最終処分場に敷設される遮 水シートを対象とし，一軸拘束一軸引張試験ならびに均

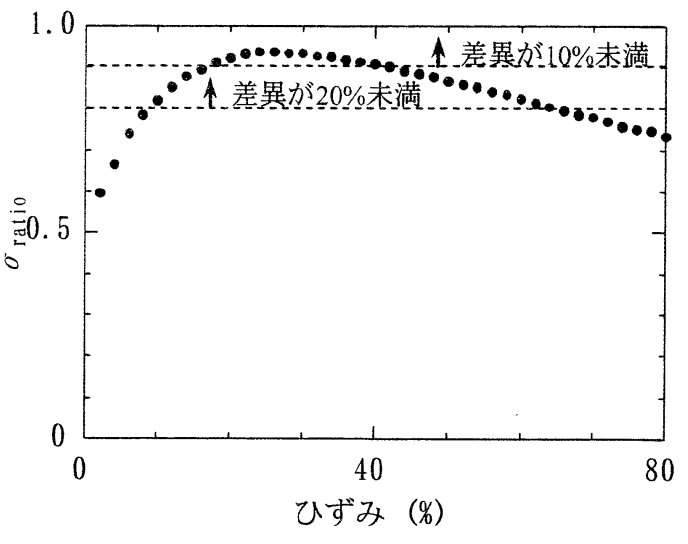

(a) 軟質PVC

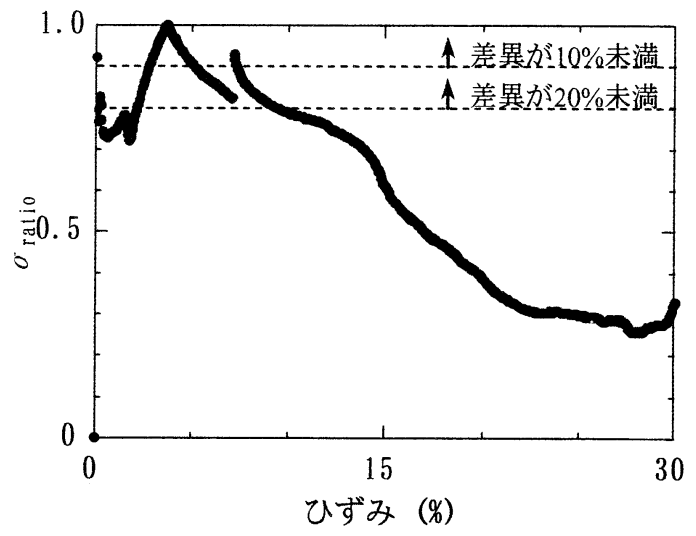

(b) HDPE

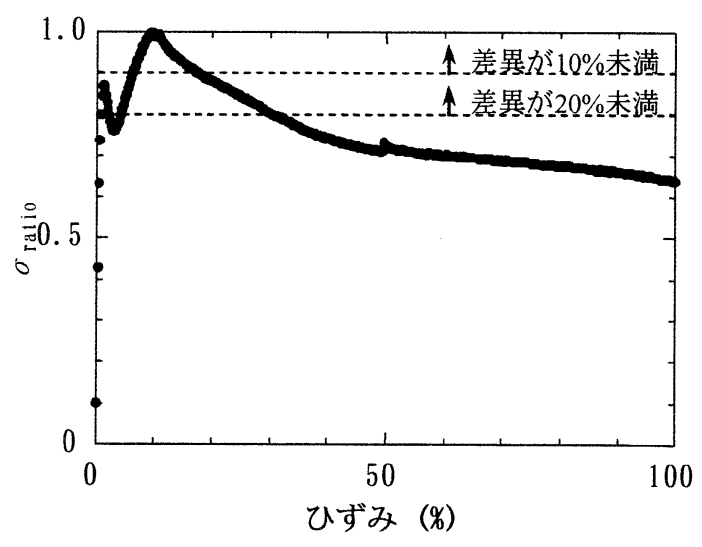

(c) SMePE

図-12 W関数による二軸引張変形時の応力の推定精度

等二軸引張試験を行った. また, 一軸拘束二軸引張試験 によって遮水シートの归数の偏微分值を求めた. さら に, 得られた関数形を用いて遮水シートの二軸引張変 形時の応力ひずみ挙動の評価を試みた．以下に得られた 結果を示す.

（1）二軸引張試験により，一軸拘束二軸引張変形時およ び均等二軸引張変形時の軟質PVC, HDPE, SMePEの各応力 ひずみ関係が明らかになった。

（2）HPPEおよびSMePEについて引張速度を変化させて均等 二軸引張試験を行った結果, 引張速度が大きい方が供試 体は高弾性，高強度であることがわかった．また，軟質 
PVCについて均等二軸引張変形中の厚さを測定した結果, 変形中の供試体の体積は80 \%ひずみにおいて変形前の約 1.15倍に増加することがわかった.

（3）鱈数を用いて均等二軸引張変形中の遮水シートの 応力ーひずみ曲線を計算した結果, どの供試体も低ひず み側では試験値と計算值の傾向はよく一致したが，高ひ ずみ側では大きなずれが生じた，さらに，䈒数による 応力ーひずみ曲線の推定精度が明らかになった。

今後は, 保護マットの二軸引張変形挙動, および遮水 シートと保護マットを重ね合わせた時の二軸引張変形挙 動について検討する予定である. また，突起物の貫入や 引き込み力作用時の引張変形等, 実際の現場を想定した 遮水シートの変形挙動に対する本推定手法の適用性につ いて，今後さらに検討を行っていく予定である. また, 二軸引張試験は一軸引張試験に比べて複雑であり, 計測 時の誤差が供試体の性能に及ぼす影響が現時点では不明 確なため, より詳細な議論をするためには同一種の供試 体による再現性の検討を行う必要性がある. なお, 本研 究の成果の一部は土木シート技術協会が大阪府産業技術 総合研究所に委託した研究の結果を活用したものである.

\section{参考文献}

1) 宮地秀樹, 今泉繁良, 吉直卓也 : 保護マットの組合せ順序 亡遮水シート貫入抵抗の関係について, 第13回廃棄物学会研
究発表会講演論文集, pp. 942-944, 2002.

2) 狩野真吾, 諸星一信, 小田勝也 : 廃棄物海面処分場遮水シ 一トの突き破り抵抗に関する研究，国土技術政策総合研究 所資料, No. 142，154p，2004.

3）平原直征，兵動正幸，村田秀一，中田幸男，吉本憲正, 黒岩正夫, 下田宏治, 松村聡, 木俣陽一, 山本和彦: 砕石 を模擬したコーンの貫入による遮水シートの損傷評価，第40 回地盤工学研究発表会発表講演集, pp. 2579-2580, 2005.

4）小竹望, 北出圭介, 鶴ヶ崎和博, 馬場慎太郎, 西野好夫, 徳㴊克正 : 管理型廃棄物海面処分場における遮水シートの 発生ひずみ, ジオシンセティックス論文集, Vol.19, pp.8186, 2004.

5）最終処分場技術システム研究会 : 廃棄物最終処分場技術シ ステムハンドブック, 730p, 1999.

6）（社）全国都市清掃会議 : 廃棄物最終処分場整備の計画 ・ 設計要領, $485 \mathrm{p}, 2001$.

7）山下義裕, 川端季雄 : 補強ゴムのひずみエネルギー密度関 数の近似式, 日本ゴム協会誌, Vol.65, No.9, pp.517-528, 1992.

8）深堀美英 : 設計のための高分子の力学, 技報堂出版, pp. 31-36, 2000.

9）狩野真吾, 小田勝也, 吉田誠, 三藤正明 : 管理型廃 革物埋立護岸遮水シートの敷設面不陸に対する変形 追随性，海洋開発論文集，Vol.20，pp. 809-814，2004.

\title{
EVALUATION OF BIAXIAL TENSILE BEHAVIOR OF WATERPROOF SHEETS BASED ON THE STRAIN ENERGY DENSITY FUNCTION
}

\author{
Shingo KANO, Katsuya ODA and Mikio KONDO
}

\begin{abstract}
In this study, we tried to examine the accuracy of estimation for stress-strain curve in biaxial extension condition which was calculated by strain energy density function of waterproof sheets laid on a seepage structure in a controlled waste disposal site. The partial differential value of the strain energy density function was determined by the pure shear test. After a comparison between calculated stress-strain curve and that from the biaxial extension test, calculated values were correspond with the testing data within $10 \%$ error for the range from 15 to $40 \%$ strain for PVC, 3 to $4 \%$ for HDPE and 6 to $15 \%$ for SMePE. The previous study says that the strain of waterproof sheet made of PVC laid on backfilling unevenness was at most $15 \%$. Thus, we suggest that the application of strain energy density function for the evaluation of waterproof sheet deformation due to unevenness of backfilling slope in a controlled waste disposal site should be possible.
\end{abstract}

Keywords: Waterproof sheet, Biaxial tensile test, Strain energy density function, Stress - strain curve. 